Jurnal Penyuluhan, Maret 2009 Vol. 5 No. 1

\title{
Keberdayaan Petani Sayuran dalam Mengakses Informasi Pertanian di Sulawesi Selatan
}

\section{The Capacity of Crop Farmers to Access Agricultural Information in South Sulawesi}

\author{
Lukman Hakim $^{*}$ dan Basita G. Sugihen ${ }^{2}$ \\ ${ }^{1}$ Fakultas Ilmu Sosial dan Ilmu Politik, \\ Universitas Muhammadiyah Makasar \\ ${ }^{2}$ Departemen Sains Komunikasi dan Pengembangan Masyarakat, \\ Fakultas Ekologi Manusia, Institut Pertanian Bogor
}

\begin{abstract}
Focus of this study is to research the capacity of crop farmers in improving their agribusiness by accessing agricultural information. The research objectives are to analyze the power of crop farmers in accessing relevant, accurate and timely information; and to analyze the relationship between accessing information, the level of empowerment of group farmers and the level of farmers productivity. This study was carried out at two districts Suchar Gowa and Enrekang at South Sulawesi Province. Primary data was collected from 240 respondents who are members of farmers group and their main activities are crop quowers. Quantitative analysis and qualitative descriptive analysis were employed to analyze the result of this study. The variables of this study are: relevance of information $\left(X_{1}\right)$; information accuracy $\left(X_{2}\right)$; timely manner of information $\left(X_{3}\right)$; the level of empowerment $\left(Y_{1}\right)$; and the level of farmers productivity $\left(Y_{2}\right)$. The capacity for farmers to access information was low. The capacity of farmers group and farmers productivity were low. The access of information had a significant relation with the level of group empowerment and the level of farmers productivity. Variables of the relevance of information and information accuracy have positive influence to the level of group capacity in accesing information. Variable of information accuracy have significant positive influence to the level of farmers productivity. Based on the relationship between variables in the model of farmers capacity to access agricultural information, it shows that variables of information accuracy and variables of task and group function were dominant and strategic factors related to farmers productivity. That means these indicators have significant role to improvement of farmers productivity.
\end{abstract}

Key words: the level of farmer empowerment, information access, and farmer productivity

\section{PENDAHULUAN}

Perkembangan arus informasi sekarang ini membuat seseorang memiliki pilihan yang lebih banyak untuk mendapatkan jenis informasi yang diinginkan. Menurut Naisbitt (Kumorotomo dan Margono, 1996), bahwa kita telah menapaki zaman baru yang dicirikan oleh adanya ledakan informasi (information explosion) beserta sepuluh kecenderungan pokok yang sesungguhnya menunjukkan bahwa kita telah beralih dari masyarakat industrial ke masyarakat informasi. Pada kenyataannya, sebagian besar kelompok masyarakat kita tinggal di wilayah terpencil, agak tertinggal dengan derasnya arus informasi dan komunikasi yang sedemikian maju. Petani di wilayah pedesaan terpencil, berhak pula menikmati pilihan dalam mengakses informasi dari berbagai sumber yang diharapkan membuka wawasan dan membangkitkan

\footnotetext{
${ }^{*}$ Korespondensi penulis. Telepon: 0811414659

E-mail: lukman_hakim@yahoo.co.id
} 


\section{Jurnal Penyuluhan, Maret 2009 Vol. 5 No. 1}

motivasi dan kinerja bertani. Oleh karena itu dalam praktek pertanian, informasi sangat penting untuk pengenalan pengetahuan dan keterampilan baru, metode-metode baru, teknologi produksi baru dan kelancaran pemasaran hasil produksi (Van den Ban dan Hawkins, 1999).

Di sisi lain, tumpukan informasi tersebut belum menjamin pemanfaatannya akan lebih baik karena tergantung bagaimana mengorganisir informasi tersebut. Lebih lanjut dikemukakan oleh Van den Ban dan Hawkins (1999), informasi merupakan sumberdaya penting di dalam pertanian modern. Perkembangan komputer dan perbaikan telekomunikasi memberikan petani kesempatan untuk memperoleh informasi teknis dan ekonomis dengan cepat dan menggunakannya dengan efektif untuk pengambilan keputusan. Diungkapkan, jumlah informasi yang dapat dan harus digunakan oleh petani untuk mengambil keputusan semakin cepat bertambah. Informasi ini meliputi laporan hasil penelitian, data pasar, data tentang pertumbuhan dan proses pengelolaan lahan pertaniannya dan yang serupa sebagai pembanding. Informasi ini digunakan untuk memilih teknologi produksi yang paling menguntungkan, menciptakan kondisi pertumbuhan yang optimal untuk tanaman dan ternaknya, menentukan anggaran pengeluaran dan melihat usaha yang paling menguntungkan serta memutuskan kapan dan dimana menjual hasilnya.

Berdasarkan pendapat tersebut, informasi bagi petani memegang peranan penting dalam membuka wawasan terhadap dunia nyata yang dihadapinya, karena informasi yang diterimanya akan merubah kebiasaan-kebiasaan sikap berusahatani, kemudian membentuk suatu sikap baru yang merupakan dampak penyesuaian informasi lama dengan sejumlah informasi baru yang diterima. Semakin banyak informasi yang diterima akan semakin banyak perubahan-perubahan untuk memenuhi kebutuhan yang belum terpuaskan dalam diri petani tersebut.

Berdasarkan hal tersebut, tujuan penelitian adalah (1) menjelaskan keberdayaan petani mengakses informasi yang relevan, akurat, dan tepat waktu untuk meningkatkan produktivitas kerjanya, dan (2) menganalisis hubungan antara akses informasi dengan keberdayaan kelompok tani dan tingkat produktivitas kerja.

\section{METODE PENELITIAN}

Populasi penelitian ini adalah seluruh petani sayuran anggota kelompok tani di wilayah penelitian yakni Kabupaten Gowa dan Enrekang pada empat kecamatan, sebanyak 2.200 orang. Sampel petani sebanyak 240 orang sebagai responden yang terpilih secara acak. Populasi kelompok adalah seluruh kelompok tani di wilayah penelitian yang berjumlah 88 kelompok. Sampel kelompok sebanyak 24 kelompok yang terpilih secara acak dari kelompok tani terpilih.

Penelitian ini menganalisis pengaruh antar peubah independen $(\mathrm{X})$ dengan keberdayaan kelompok $\left(\mathrm{Y}_{1}\right)$, dan tingkat produktivitas kerja petani $\left(\mathrm{Y}_{2}\right)$. Untuk itu penelitian ini dirancang dalam bentuk explanatory research yang bertujuan menjelaskan pola hubungan dan pengaruh antar peubah melalui pengujian hipotesis.

Data dan obyek pengamatan dari penelitian ini terdiri atas tiga peubah bebas dan dua peubah terikat, yakni (1) relevansi informasi $\left(\mathrm{X}_{1}\right)$, (2) akurasi informasi $\left(\mathrm{X}_{2}\right)$, dan (3) ketepatan waktu informasi $\left(\mathrm{X}_{3}\right)$. Kemudian peubah terikat adalah keberdayaan kelompok tani $\left(\mathrm{Y}_{1}\right)$, dan tingkat produktivitas kerja petani $\left(\mathrm{Y}_{2}\right)$. Instrumentasi penelitian berkaitan dengan alat pengukur yang digunakan dalam pengumpulan data penelitian. Instrumen yang dipersiapkan untuk mengumpulkan data penelitian ini adalah kuesioner yang berisi butir-butir pertanyaan yang berhubungan dengan peubah/variabel penelitian. Kusioner tersebut berisi pertanyaan tertutup dimana jawaban sudah ditentukan terlebih dahulu, dan terdapat pula pertanyaan yang bersifat terbuka dimana responden diberi kesempatan memberi jawaban lain. Hasil uji validitas item instrumen (r-hitung) berkisar 0,624 s.d 0,712 pada taraf signifikan 95\%. Dengan demikian instrumen yang digunakan cukup valid. Hasil uji reliabilitas instrumen dengan metode Cronbach 


$$
\text { Jurnal Penyuluhan, Maret } 2009 \text { Vol. } 5 \text { No. } 1
$$

Alpha memperoleh koefisien sekitar 0,639 s.d 0,983 atau instrumen dianggap cukup reliabel sebagai alat ukur.

Data penelitian terdiri atas data primer dan data sekunder. Data primer dikumpulkan dengan menggunakan kuesioner baik yang bersifat tertutup maupun yang bersifat terbuka. Pengumpulan data yang dilakukan dengan teknik wawancara. Untuk memperkuat objektifitas data dilakukan pula pengamatan dan wawancara semi terstruktur tentang akses informasi pertanian oleh kelompok tani. Data sekunder bersumber dari instansi terkait serta hasil studi kepustakaan. Selain responden sampel, informasi diperoleh pula dari sejumlah informan dari Dinas Pertanian Gowa dan Enrekang di Sulawesi Selatan.

Penelitian ini menganalisis berbagai bentuk hubungan antar peubah sekaligus menguji hipotesis, yakni: (1) untuk menganalisis tingkat keberdayaan petani mengakses informasi yang relevan, akurat dan tepat waktu, digunakan analisis statistik deskriptif berdasarkan persentase, (2) untuk menganalisis keterkaitan hubungan antar variabel $\mathrm{X}$ dan $\mathrm{Y}$, digunakan analisis korelasi Kendall's Tau, dan (3) untuk menganalisis hubungan pengaruh antara berbagai variabel $\mathrm{X}$ dengan $\mathrm{Y}$ digunakan analisis regresi linier berganda, (4) untuk memperluas analisis antar peubah digunakan analisis jalur (path analysis) (Supranto, 2004).

\section{HASIL DAN PEMBAHASAN}

\section{Keberdayaan Petani dalam Mengakses Informasi}

Sebagaimana terlihat dalam Tabel 1, secara umum keberdayaan petani dalam mengakses informasi menunjukkan adanya keseimbangan antara kategori rendah dan tinggi yakni 50 persen responden dengan kategori rendah dan 50 persen responden dengan ketegori tinggi. Artinya separuh petani dari dua lokasi mampu mengakses informasi yang relevan, akurat dan tepat waktu dan sebagian lagi kurang mampu mengakses secara maksimal. Dua dari tiga unsur dalam mengakses informasi yakni unsur relevansi informasi dan akurasi informasi masing-masing berada pada kategori rendah, sedangkan unsur ketepatan waktu informasi menunjukkan keseimbangan antara kategori rendah dan tinggi. Dilihat per lokasi sebanyak 55,8 persen responden di Kabupaten Gowa mengakses informasi dengan kategori tinggi dan 44,8 persen responden di Kabupaten Enrekang mengakses informasi dengan kategori tinggi.

Tabel 1. Sebaran Responden menurut Akses pada Informasi di Kabupaten Gowa dan Enrekang Provinsi Sulawesi Selatan, 2007

\begin{tabular}{|c|c|c|c|c|}
\hline \multirow{2}{*}{$\begin{array}{l}\text { Unsur Akses Pada } \\
\text { Informasi }\end{array}$} & \multirow[t]{2}{*}{ Kriteria } & \multicolumn{2}{|c|}{ Kabupaten } & \multirow[t]{2}{*}{ Total } \\
\hline & & Gowa & Enrekang & \\
\hline
\end{tabular}

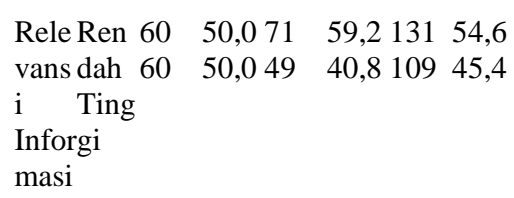




\section{Jurnal Penyuluhan, Maret 2009 Vol. 5 No. 1}

Tidak ada perbedaan dalam mengakses informasi diantara dua lokasi $(\alpha=0,05)$. Artinya kegiatan petani mengakses jenis informasi di dua lokasi menunjukkan adanya keseragaman jenis. Meskipun jenis informasi yang dibutuhkan cenderung tidak berbeda, namun kemampuan petani untuk memper-olehnya ditentukan oleh beberapa faktor. Menurut Ahmad (1984), kemampuan sese-orang mendapatkan dan menyerap informasi ditentukan antara lain oleh faktor pendidikan, kesempatan (waktu), jarak domisili dari sumber informasi dan kemampuan ekonomi yang dimiliki. Di lokasi penelitian, peubah akses pada informasi berhubungan positif dan nyata dengan peubah tingkat pendidikan formal petani $(\mathrm{r}=0,157 ; \alpha=0,05)$. Artinya jika pendidikan formal petani mengalami pening-katan maka kemampuan mengakses informasi akan semakin baik dan sebaliknya jika tingkat pendidikan formal rendah maka kemampuan mengakses informasi juga akan rendah.

\section{Keberdayaan Kelompok Tani}

Kapasitas kelompok tani dalam penelitian ini dilihat dari kemampuan kelompok mencapai tujuan, pelaksanaan fungsi dan tugas kelompok, pembinaan dan pengembangan kelompok, serta kekompakan kelompok. Unsur-unsur dinamika kelompok tersebut merupakan energi atau kekuatan-kekuatan yang terdapat dalam situasi kelompok yang diwujudkan dalam bentuk perilaku kelompok dan anggota-anggotanya. Dalam psikologi sosial disebutkan bahwa kelompok mempunyai perilaku, demikian juga anggotanya yang dipengaruhi oleh unsur-unsur dinamika kelompok. Unsur-unsur dinamika kelompok tersebut akan mendukung dan menjamin keberlanjutan kehidupan kelompok baik dari sisi kehidupan sosial maupun kehidupan ekonomi bagi anggota-anggotanya.

Tabel 2. Sebaran Persepsi Responden tentang Kedinamisan Kelompokdi Kabupaten Gowa dan Enrekang Provinsi Sulawesi Selatan, 2007

\begin{tabular}{|c|c|c|c|c|}
\hline Unsur & & Kabupaten & & Total \\
\hline Dinamika Kelompok & Kriteria & Gowa & Enrekang & \\
\hline
\end{tabular}

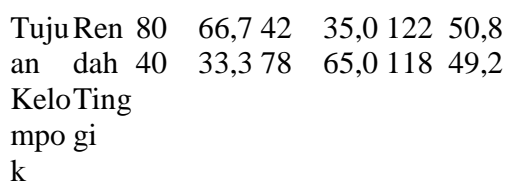

Secara umum, keberdayaan kelompok (Tabel 2) yang dicermati dari pengembangan unsur-unsur kekuatan atau dinamika kelompok di dua lokasi penelitian menunjukkan rata-rata kategori rendah yakni 51,3 persen responden dan hanya 48,7 persen dalam kategori tinggi. Di antara empat unsur dinamika kelompok, unsur yang masuk kategori terendah adalah pengembangan fungsi tugas yakni 53,3 persen, menyusul unsur pembinaan dan pengembangan kelompok yakni 53,0 persen. Hal ini berarti bahwa pengembangan fungsi dan tugas dalam 


\section{Jurnal Penyuluhan, Maret 2009 Vol. 5 No. 1}

kelompok kurang dilaksanakan sesuai tujuan kelompok yang ingin dicapai. Setiap anggota kelompok seharusnya sudah mengetahui fungsi dan tugas yang harus dijalankan, dan kekurang berdayaan petani menjalankan fungsi tugas masing-masing karena kurangnya inisiasi, kordinasi dan kerjasama dalam kelompok. Rendahnya kemampuan anggota melakukan inisiasi atau prakarsa sendiri karena kurangnya pemahaman terhadap tugas itu sendiri. Oleh karena itu pertemuan-pertemuan rutin anggota kelompok sangat diperlukan.

\section{Hubungan antara Akses Informasi dengan Keberdayaan Kelompok Tani}

Hasil uji korelasi (Tabel 3) menunjukkan, semua peubah akses informasi yang meliputi: relevansi informasi, akurasi informasi, dan ketepatan waktu informasi berhubungan positif dan nyata dengan keberdayaan kelompok dan tingkat produktivitas kerja, artinya informasi yang diakses petani memiliki tingkat relevansi dan urgensi yang tinggi terhadap keberdayaan kelompok dan peningkatan produktivitas kerja petani. Demikian pula hasil uji persamaan regresi (Tabel 3) menunjukkan bahwa peubah relevansi informasi dan akurasi informasi berpengaruh positif dan nyata terhadap keberdayaan kelompok. Peubah ketepatan waktu informasi tidak berpengaruh terhadap keberdayaan kelompok.

Tabel 3. Nilai Koefisien Korelasi Kendall Tau dan Koefisien Regresi antar Peubah Akses Informasi dengan Keberdayaan Kelompok dan Tingkat Produktivitas Kerja

\begin{tabular}{lllll}
\hline \multirow{2}{*}{ Variabel Independen $(\mathrm{X})$} & \multicolumn{2}{c}{ Koefisien Korelasi } & \multicolumn{2}{c}{ Koefisien Regresi } \\
\cline { 2 - 5 } & $\mathrm{Y}_{1}$ & $\mathrm{Y}_{2}$ & $\mathrm{Y}_{1}$ & $\mathrm{Y}_{2}$ \\
\hline Relevansi Informasi $\left(\mathrm{X}_{1}\right)$ & $0,435^{* *}$ & $0,259^{* *}$ & $0,285^{* *}$ & 0,125 \\
Akurasi Informasi $\left(\mathrm{X}_{2}\right)$ & $0,403^{* *}$ & $0,252^{* *}$ & $0,344^{* *}$ & $0,334^{* *}$ \\
Ketepatan Waktu Informasi $\left(\mathrm{X}_{3}\right)$ & $0,435^{* *}$ & $0,250^{* *}$ & 0,090 & $-0,035$ \\
\hline
\end{tabular}

Keterangan: $* *$ nyata pada $\alpha=0,01$

Hal ini berarti, kelompok tani sebagai media pembelajaran petani dapat dikembangkan dengan tersedianya informasi yang relevan dengan kebutuhan petani, dan informasi yang akurat atau terpercaya. Demikian pula peubah akurasi informasi berpengaruh positif dan nyata dengan tingkat produktivitas kerja petani, dan peubah relevansi informasi dan ketepatan waktu informasi tidak berpengaruh. Fakta ini menunjukkan bahwa dalam meningkatkan produktivitas kerja petani hanya dapat dilakukan dengan adanya informasi yang akurat atau terpercaya yang diperoleh petani. Dengan demikian jika peubah-peubah tersebut membaik, akan semakin baik pula keberda-yaan kelompok dan tingkat produktivitas kerja petani.

\section{Jalur Hubungan antar Peubah Akses Informasi dan Keberdayaan Kelompok terhadap Tingkat Produktivitas Kerja Petani}

Berdasarkan diagram analisis jalur tentang hubungan antara semua peubah akses informasi dan keberdayaan kelompok terha-dap produktivitas kerja petani (Gambar 1), tampak bahwa terdapat tiga jalur hubungan antar peubah yang mempunyai koefisien jalur yang signifikan terhadap tingkat produktivitas kerja petani. Jalur tersebut adalah: (1) jalur hubungan 


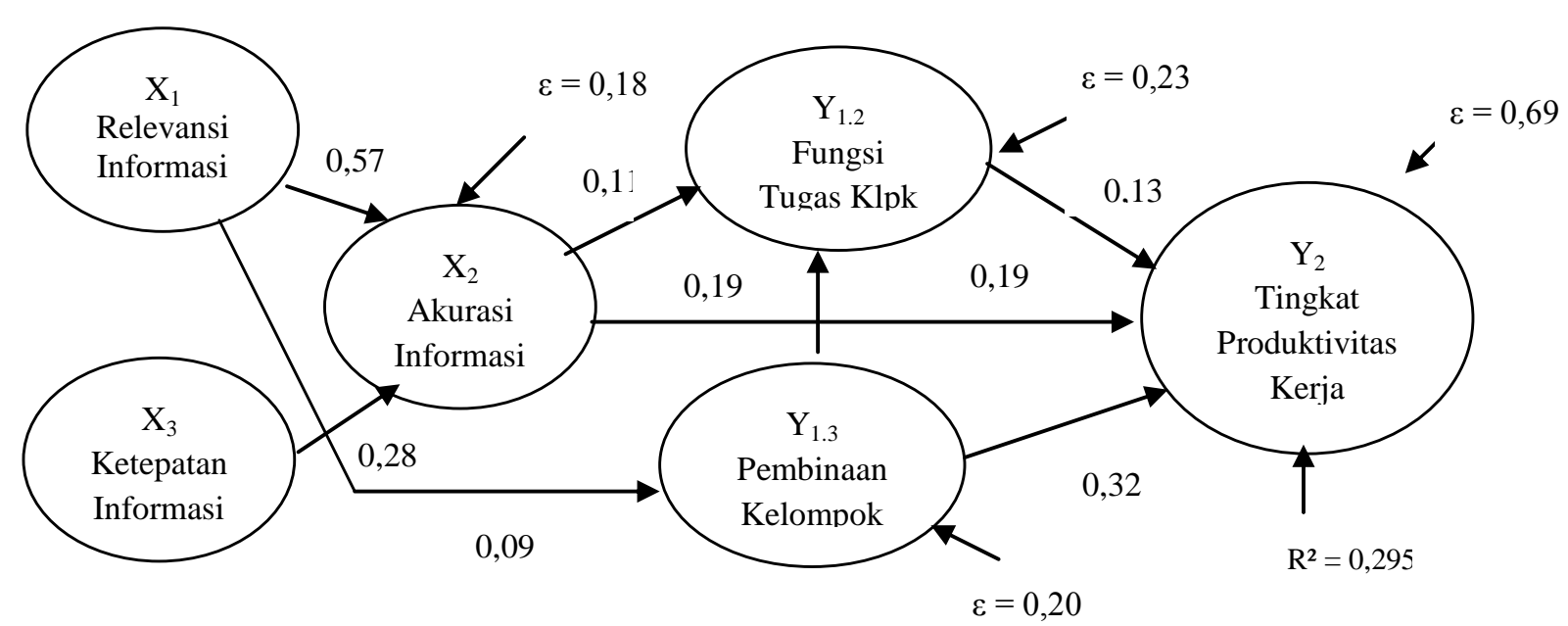

Gambar 1. Jalur Hubungan antar Peubah Akses Informasi dan Keberdayaan Kelompok Terhadap Tingkat Produktivitas Kerja Petani

langsung antar peubah terhadap tingkat produktivitas kerja petani dengan nilai $\mathrm{R}^{2}$ sebesar 0,295 ; (2) jalur hubungan tidak langsung melalui peubah akurasi informasi dengan nilai $\mathrm{R}^{2}$ sebesar 0,819; dan (3) jalur hubungan tidak langsung melalui peubah fungsi dan tugas kelompok dengan nilai $\mathrm{R}^{2}$ sebesar 0,767 .

Peubah relevansi informasi dan ketepatan waktu informasi memiliki pengaruh tidak langsung lebih tinggi terhadap tingkat produktivitsa kerja petani jika dipadukan dengan peubah akurasi informasi. Artinya keberdayaan petani dalam meningkatkan produktivitas kerjanya dapat tercapai jika mereka mendapat informasi yang terpercaya. Hal ini sejalan dengan Van den Ban dan Hawkins (1999) bahwa yang penting bagi petani adalah mendapatkan informasi yang jujur dan terpercaya serta mudah dimengerti.

Informasi yang jujur dan terpercaya berpengaruh terhadap keberdayaan kelompok tani dengan nilai koefisien sebesar 0,111. Fenomena ini mengindikasikan bahwa komunikasi dan kerjasama untuk member-dayakan kelompok hanya dapat tercapai jika informasi yang diperoleh petani dalam kelompok dapat dipercaya. Demikian pula fungsi dan tugas anggota kelompok tani akan lebih mampu memecahkan masalah dan mendapatkan solusi terbaik, jika informasi yang diperoleh sesuai dengan keadaan yang sebenarnya. Dengan demikian bagi petani, bukan hanya butuh dengan informasi yang relevan dengan usahanya dan bisa diperoleh saat dibutuhkan, tetapi yang lebih penting adalah informasi tersebut dapat diyakini kebenarannya.

Salah satu jenis informasi yang diharapkan petani adalah informasi yang relevan dengan usahataninya. Sebanyak 54,6 persen responden di dua lokasi belum dapat mengakses informasi yang relevan atau sesuai dengan yang diharapkan. Jenis informasi yang diharapkan petani antara lain adalah (1) informasi pengetahuan dan keterampilan usahatani, (2) informasi harga produk usahatani, (3) informasi keberhasilan petani lain, (4) informasi harga sarana produksi, (5) informasi tentang pelatihan usaha, (6) informasi permodalan, dan (7) informasi peralatan teknis usahatani.

Kesulitan sebagian petani mengakses informasi tentang pembangunan pertanian dan pedesaan dikarenakan oleh keterbatasan kemampuan petani dalam pengadaan media komunikasi seperti surat kabar, majalah dan televisi, juga karena arus komunikasi dari media kurang mempublikasikan masalah-masalah pembangunan pertanian yang dibutuhkan petani. Dalam mengakses informasi yang relevan dengan kebutuhan, sebagian responden di dua lokasi 
Jurnal Penyuluhan, Maret 2009 Vol. 5 No. 1

memperoleh informasi melalui kontak langsung dengan berbagai sumber yakni dari para penyuluh, tokoh informal, tokoh formal (aparat desa dan camat), keluarga, dan tetangga. Sebagian lagi mengakses dan dari media massa (radio, tv, surat kabar, dan sumber lainnya). Peubah akses informasi mempunyai hubungan yang positif dan nyata dengan peubah peranan tokoh informal $(\mathrm{r}=0,743 ; \alpha=0.01)$. Hal ini berarti, tokoh informal merupakan salah satu saluran komunikasi penting dalam mengakses informasi.

Dalam perkembangan teknologi ko-munikasi dan informasi sekarang ini peranan media massa dalam penyebaran informasi sangat membantu khususnya radio dan televisi. Meskipun demikian pesan informasi yang disampaikan lebih tanggap terhadap masalah-masalah industri alat pertanian, pejabat-pejabat pemerintah di bidang pertanian, dan para pembeli produksi tani dari pada terhadap para produsennya sendiri (Depari dan Mac Andrews, 2006).

Informasi Radio Republik Indonesia di Sulawesi Selatan sangat akrab dengan pemirsa di kawasan pedesaan Indonesia Timur (Depari dan Mac Andrews, 2006). Informasi masalah pembangunan pertanian terpublikasi lewat siaran pedesaan yang disiarkan dalam Programa I (regional) RRI Nusantara IV Makassar. Realisasi jam siaran yang telah disiarkan selama tahun 2004 sebanyak 315 jam atau 4,53 persen dari total jam siaran. Alokasi jumlah jam siaran pedesaan tersebut masih tergolong kecil dibandingkan dengan porsi waktu untuk jenis siaran warta berita 1056 jam, siaran peristiwa hangat 108 jam dan siaran penerangan umum sebanyak 576 jam.

Jangkauan informasi pembangunan pedesaan melalui radio diperoleh setiap pagi pukul 07.15 dan di malam hari lewat siaran iklan tentang pembangunan pedesaan dan iklan tentang tanaman sayuran serta tanaman perkebunan. Minimnya waktu untuk siaran pembangunan pertanian dan pedesaan tersebut menentukan besar kecilnya pemirsa yang mendengarkannya. Kemampuan petani di lokasi penelitian dalam mengakses informasi mayoritas melalui radio dari pada melalui media televisi dan surat kabar. Keterbatasan membaca informasi/berita melalui surat kabar selain karena masalah biaya atau iuran bulanan juga karena terbatasnya jumlah oplah surat kabar yang terbit dan beredar di daerah pedesaan Sulawesi Selatan.

Di Sulawesi Selatan, terbit dan beredar 8 surat kabar harian dengan jumlah oplah sebanyak 139.025 eksemplar, 14 harian mingguan dengan oplah sebanyak 30.000 eksemplar dan 2 harian bulanan oplah sebanyak 250 eksemplar. Persentase informasi/berita tentang pembangunan pertanian yang dipublikasikan jumlahnya tidak menentu dan belum ditetapkan, melainkan tergantung urgensi dan aktualisasi informasi dari berita tersebut (BPS Provinsi Sulawesi Selatan, 2005)

Jumlah masyarakat perkotaan dan pedesaan yang mendengar radio sebanyak 50,96 persen dari jumlah penduduk yang berusia di atas 10 tahun. Gambaran jumlah persentase penduduk yang berusia 10 tahun keatas yang mendapat informasi/berita atau yang mendengarkan informasi dalam wilayah Sulawesi Selatan sebagaimana terlihat dalam Tabel 4.

Data tersebut menunjukkan bahwa radio dan televisi merupakan media yang terbanyak didengarkan dan ditonton masya-rakat di perkotaan dan pedesaan. Dibandingkan dengan Jawa Barat, kesempatan mendengarkan radio dan menonton televisi serta membaca surat kabar masih lebih tinggi. Kenyataan tersebut mengindikasikan bahwa rendahnya jumlah penduduk yang mendengar, menonton dan membaca informasi merupakan indikator rendahnya aktivitas petani mengakses informasi melalui media. Oleh sebab itu, saluran komunikasi lainnya melalui kontak personal dengan penyuluh, tokoh informal, tokoh formal, teman/sahabat, tetangga baik di balai desa, mesjid, dan di tempat lainnya menjadi sangat penting dalam membantu penyebaran informasi. 
Tabel 4. Penduduk Berumur 10 Tahun ke Atas yang Mendapatkan dan Mendengarkan Informasi/Berita Tahun 2003 di Wilayah Perkotaan dan Pedesaan di Sulawesi Selatan

\begin{tabular}{lcc}
\hline Kegiatan & Jumlah (\%) & $\begin{array}{c}\text { Perbandingan dengan } \\
\text { Jawa Barat }\end{array}$ \\
\hline 1. Mendengarkan Radio & 50,96 & 55,58 \\
2. Menonton Acara TV & 67,66 & 82,66 \\
3. Akses Situs Internet & 0,66 & 0,79 \\
4. Membaca Selama & & \\
Seminggu untuk jenis & & \\
- Surat Kabar & 34,35 & 42,67 \\
- Majalah/Tabloid & 19,60 & 22,37 \\
- Buku Cerita & 21,31 & 15,32 \\
\hline
\end{tabular}

Sumber : Data Sekunder diolah Berdasarkan Statistik Sosial Budaya, Hasil Susenas 2003, BPS JakartaIndonesia.

\section{Akurasi Informasi}

Pengalaman petani mendapatkan informasi yang relevan tapi kurang akurat menjadi kenyataan di lokasi penelitian. Sebanyak 64,6 persen responden dengan kategori rendah mengakui kurang mendapatkan informasi yang akurat atau terpercaya sesuai harapan mereka. Informasi yang diperoleh dari media massa sering kurang sesuai dengan kenyataan di lapangan. Jenis informasi yang sering kurang akurat antara lain informasi harga pupuk, harga pestisida, kualitas varietas, informasi harga produk, informasi jumlah produksi yang dibutuhkan pedagang, dan lain-lainnya.

Media massa seperti televisi, radio dan beberapa eksemplar surat kabar telah menyebar sampai di wilayah pedesaan lokasi penelitian. Diantara media massa tersebut, responden menganggap radio merupakan medium yang akrab bagi mereka dan menyiarkan informasi yang dapat dipercaya melalui siaran pedesaan. Pada dasarnya petani selalu mencari informasi akurat yang valid. Kesadaran dan minat menggunakan hal-hal baru berdasarkan informasi yang diperoleh, akan tumbuh ketika hal-hal baru tersebut terbukti hasilnya dan mendatangkan keuntungan bagi mereka. Seperti halnya petani kentang di Kabupaten Gowa, pengalaman mendapatkan informasi mengenai varietas kentang yang unggul dengan produksi yang tinggi membuat petani bersemangat menggarap kebun miliknya dan kebun di lahan-lahan yang satu tahun terakhir kurang dimanfaatkan. Hal ini berarti bahwa informasi yang terbukti benar menumbuhkan kesadaran dan semangat berusahatani. Hal itu berkaitan pula dengan pengalaman keberhasilan suatu inovasi. Jika inovasi tersebut berhasil maka petani mudah mempercayainya, tetapi jika gagal maka petani akan menggunakan input dan cara lama sesuai kebiasaan yang pernah dilakukan.

Sebagian petani sayuran di Kabupaten Gowa khususnya di Kecamatan Barombong yang bersebelahan dengan Kota Makassar memiliki akses informasi yang diharapkan dan lebih mudah terjangkau. Sebaliknya petani di Kabupaten Enrekang selain mengakses informasi dari pos informasi tani di setiap desa, juga memperoleh langsung dari para penyuluh dan tokoh masyarakat dan aparat pemerintah (tokoh formal). Dengan demikian informasi yang akurat merupakan syarat pokok yang menjamin kelangsungan usahatani, dan penyuluh dapat berperan sebagai fasilitator yang membantu tersedianya akses informasi tersebut. 


\section{Ketepatan Waktu Informasi}

Ketepatan waktu mendapatkan informasi merupakan hal yang sangat penting agar semua input dan kebutuhan usahatani yang diperlukan tersedia pada waktu dan tempat yang tepat. Berdasarkan penelitian di dua lokasi bahwa ketepatan waktu mendapatkan informasi yang dibutuhkan menunjukkan adanya keseimbangan antara kategori rendah dan tinggi. Artinya separuh responden mengakui mendapatkan informasi tepat waktu saat dibutuhkan dan sebagian responden tidak mendapatkan informasi pada waktu yang tepat.

Pada saat tertentu khususnya di musim tanam, petani berkeinginan mengakses informasi persediaan pupuk, obat pembunuh hama, benih yang baik dan alat-alat pertanian yang sederhana agar mudah memperolehnya. Kendala yang dihadapi adalah, untuk memperoleh informasi tersebut, petani harus menghubungi pedagang bahan-bahan pertanian di Makassar. Sebagai akibatnya, petani harus meluangkan waktu dan mengeluarkan biaya transportasi tambahan.

Upaya pelayanan pemberian informasi yang tepat waktu kepada petani diusahakan oleh Dinas Pertanian Tanaman Pangan Kabupaten Enrekang melalui pembangunan pusat informasi tani, namun usaha tersebut belum terwujud seiring pembangunannya bersamaan dengan pembangunan terminal bisnis sayuran di Kecamatan Alla Kabupaten Enrekang. Pelayanan informasi tani di Kabupaten Gowa masih berpusat pada BPP kecamatan dan Balai Informasi Penyuluhan Pertanian Tanaman Pangan dan Kehutanan (BIPPTPH) setempat. Di tempat ini, fasilitas pelayanan informasinyapun terbatas. Oleh sebab itu, peranan kelompok tani sebagai wadah memperlancar arus informasi menjadi sangat penting di tengah permasalahan sulitnya sebagian petani mengakses informasi yang dibutuhkan. Selain itu, dukungan sarana telekomunikasi sangat diperlukan terutama dalam memperlancar informasi antar kelompok. Masalahnya dalam mengakses fasilitas komunikasi tersebut dihadapkan dengan keterbatasan petani mempersiapkan biaya untuk itu dan hal ini merupakan persoalan tambahan bagi petani di tengah masih rendahnya pendapatan mereka.

\section{KESIMPULAN}

Keberdayaan petani mengakses informasi pertanian, baik informasi yang relevan, akurat, dan informasi yang tepat waktu di kedua lokasi masih rendah. Dua dari tiga unsur dalam mengakses informasi yakni unsur relevansi informasi dan akurasi informasi masing-masing berada pada kategori rendah. Lebih dari separuh petani di Kabupaten Gowa telah mampu mengakses informasi pertanian yang relevan, sedangkan di Kabupaten Enrekang terjadi sebaliknya yaitu belum mampu mengakses informasi yang relevan.

Informasi yang diakses petani memiliki tingkat relevansi dan urgensi yang tinggi terhadap keberdayaan kelompok dan peningkatan produktivitas kerja petani.

Komunikasi dan kerjasama yang baik dalam kelompok hanya dapat tercapai jika informasi pertanian yang diperoleh petani dapat dipercaya. Dengan demikian kelompok tani sebagai media pembelajaran dapat dikembangkan dengan tersedianya informasi yang relevan dan terpercaya. Demikian pula untuk meningkatkan produktivitas kerja petani hanya dapat dilakukan dengan adanya informasi yang akurat atau terpercaya.

\section{DAFTAR PUSTAKA}

Kumorotomo, W., dan Subando AM. 1996. Sistem Informasi Managemen. Yokyakarta: Gadjah Mada University Press

Supranto. 2004. Analisis Multivariat: Arti dan Interpretasi. Jakarta: Rineka Cipta

van den Ban, A.W, and H.W. Hawkins. 1999. Penyuluhan Pertanian. (Terjemahan) Oleh: Agnes

Dwina Herdiasti.Yokyakarta: Penerbit Kanisius 